\title{
Grazing history effects on above- and below-ground litter decomposition and nutrient cycling in two co-occurring grasses
}

\author{
María Semmartin • Lucas A. Garibaldi • \\ Enrique J. Chaneton
}

Received: 27 July 2007 / Accepted: 19 November 2007 / Published online: 9 December 2007

(C) Springer Science + Business Media B.V. 2007

\begin{abstract}
Large herbivores may alter carbon and nutrient cycling in soil by changing above- and below-ground litter decomposition dynamics. Grazing effects may reflect changes in plant allocation patterns, and thus litter quality, or the site conditions for decomposition, but the relative roles of these broad mechanisms have rarely been tested. We examined plant and soil mediated effects of grazing history on litter mass loss and nutrient release in two grazing-tolerant grasses, Lolium multiflorum and Paspalum dilatatum, in a humid pampa grassland, Argentina. Shoot and root litters produced in a
\end{abstract}

Responsible Editor: Alfonso Escudero.

M. Semmartin $(\bowtie) \cdot$ E. J. Chaneton

IFEVA-CONICET, Departamento de Recursos

Naturales y Ambiente, Facultad de Agronomía,

Universidad de Buenos Aires,

Av. San Martín 4453,

C1417DSE Buenos Aires, Argentina

e-mail: semmartin@ifeva.edu.ar

\section{A. Garibaldi}

Departamento de Producción Animal,

Facultad de Agronomía, Universidad de Buenos Aires,

Av. San Martín 4453,

CPA1417DSE Buenos Aires, Argentina

Present address:

L. A. Garibaldi

Laboratorio Ecotono,

Universidad Nacional del Comahue,

Quintral 1250,

8400 Bariloche, Argentina common garden by conspecific plants collected from grazed and ungrazed sites were incubated under both grazing conditions. We found that grazing history effects on litter decomposition were stronger for shoot than for root material. Root mass loss was neither affected by litter origin nor incubation site, although roots from the grazed origin immobilised more nutrients. Plants from the grazed site produced shoots with higher cell soluble contents and lower lignin:N ratios. Grazing effects mediated by shoot litter origin depended on the species, and were less apparent than incubation site effects. Lolium shoots from the grazed site decomposed and released nutrients faster, whereas Paspalum shoots from the grazed site retained more nutrient than their respective counterparts from the ungrazed site. Such divergent, species-specific dynamics did not translate into consistent differences in soil mineral $\mathrm{N}$ beneath decomposing litters. Indeed, shoot mass loss and nutrient release were generally faster in the grazed grassland, where soil $\mathrm{N}$ availability was higher. Our results show that grazing influenced nutrient cycling by modifying litter breakdown within species as well as the soil environment for decomposition. They also indicate that grazing effects on decomposition are likely to involve aerial litter pools rather than the more recalcitrant root compartment.

Keywords Flooding Pampa · Grassland · Herbivory · Nitrogen $\cdot$ Phosphorus $\cdot$ Roots 


\section{Introduction}

Large herbivores act as major drivers of terrestrial biogeochemical cycles, as they regulate carbon and nutrient fluxes linking the producer and decomposer subsystems (McNaughton et al. 1997; De Mazancourt et al. 1998; Bardgett and Wardle 2003). In particular, herbivory may influence organic matter decomposition and nutrient cycling rates by changing the quality of plant litter entering the soil through both above and belowground pathways (Holland and Detling 1990; Pastor et al. 1993; Bardgett et al. 1998; Olofsson and Oksanen 2002; Wardle et al. 2002). Moreover, prior grazing history may either accelerate or retard nutrient release from litter by altering the soil environment for decomposition (Shariff et al. 1994; Bardgett et al. 1998; Sankaran and Augustine 2004). While grazing effects on decomposition have been shown in a number of studies, few have examined the relative roles of litter quality and site conditions as intermediary factors (Olofsson and Oksanen 2002; Garibaldi et al. 2007), and how they might differentially involve aerial and root fractions of grazing-tolerant species.

Grazing effects on decomposition can be mediated by physiological changes at the whole-plant level that in turn influence the quality of litter returned to soil by grazing-tolerant species (Holland et al. 1992; Bardgett and Wardle 2003). Herbivores may drastically change patterns of energy and nutrient allocation in plants (Jaramillo and Detling 1988; Dyer et al. 1991). Plant regrowth following defoliation often increases nutrient concentrations in aerial tissues, which may thus enhance subsequent decomposition rates of senescent shoots (Ruess and McNaughton 1987; Holland et al. 1992). Grazing also affects root tissue chemistry through changes in carbon allocation and nutrient uptake (McNaughton and Chapin 1985; Jaramillo and Detling 1988; Holland and Detling 1990), having potentially variable effects on root litter breakdown (Bardgett et al. 1998; Semmartin et al. 2004). It has been suggested for certain plant species that grazing may favour morphotypes with highly decomposable litter that releases nutrients rapidly during decomposition (Holland et al. 1992; Olofsson and Osksanen 2002; Semmartin and Ghersa 2006). High herbivory pressure could alternatively promote grazing-resistant genotypes carrying traits such as low shoot $\mathrm{N}$ contents or greater allocation to roots (Coughenour et al. 1985; Dyer et al. 1991; Painter et al. 1993), which may eventually retard decomposition and nutrient mineralisation (Pastor and Cohen 1997). Intraspecific genetic differences associated with plant resistance to invertebrate herbivory have also been found to influence leaf-litter decomposition rates in old fields (Uriarte 2000) and woodlands (Madritch and Hunter 2002; Schweitzer et al. 2005). Noticeably, however, whereas grazing-induced effects on aerial litter quality and decomposition have been addressed by several studies (Bardgett and Wardle 2003; Garibaldi et al. 2007), analogous functional changes in root litter have rarely been considered (Moretto et al. 2001). In grassland ecosystems, a major fraction of plant carbon and nutrients transferred to soil go through the belowground pathway (Parton et al. 1988; Chaneton et al. 1996; Piñeiro et al. 2006). Despite the prominent role of root turnover in grassland biogeochemistry, little is known about the magnitude and direction of grazing effects on belowground litter decomposition as compared to those induced through aerial litter.

Large herbivores may additionally affect nutrient cycling by altering the soil biotic and abiotic conditions for decomposition (Shariff et al. 1994; Bardgett et al. 1998). Dung and urine deposition by grazing animals exert a powerful influence on soil nutrient pools and microbial communities (Seagle and McNaughton 1992; Bardgett et al. 2001; Sankaran and Augustine 2004). As a result, grazers have been found to enhance soil nitrogen availability and litter breakdown (Shariff et al. 1994; McNaughton et al. 1997; Tracy and Frank 1998; Olofsson and Oksanen 2002), with concomitant shifts in functional composition of the soil biota (Bardgett et al. 2001; Grayston et al. 2004). Long-term grazing may select for soil decomposers adapted to degrade litter from grazingtolerant species leading to positive plant-soil feedbacks in nutrient cycling (Bardgett and Wardle 2003). On the other hand, plant biomass removal and soil trampling associated with heavy grazing may alter soil properties such as bulk density, moisture and salinity contents (Lavado and Taboada 1988), while decreasing microbial community biomass (Sankaran and Augustine 2004), to the extent that may negatively impact on decomposition rates. However, few studies have been designed to untangling changes in nutrient cycling driven by the imprint of prior grazing history on soil conditions for decomposition and by whole-plant shifts in the quality of litter inputs to soil (cf. Schweitzer et al. 2005). 
We examined plant and soil mediated effects of grazing history on litter decomposition and nutrient turnover in two grazing-tolerant grass species. Shoot and root litter produced under common garden conditions by Lolium multiflorum Lam. and Paspalum dilatatum Poir. plants collected from long-term grazed and ungrazed sites were incubated at both grazing conditions in a Flooding Pampa grassland, Argentina. By reciprocally incubating the litter shed by conspecifics from grazed and ungrazed areas, we were able to decouple effects of prior grazing driven by litter functional attributes from those associated with the decomposition environment. Furthermore, we homogenised canopyrelated differences between grazed and ungrazed areas by removing all aerial vegetation, which allowed us to focus on soil mediated effects of grazing history on litter breakdown. We specifically asked (1) how litter origin and incubation site, singly or interactively, influence litter decomposition of two co-occurring grasses, and (2) whether grazing history affects decomposition dynamics in a consistent way for shoot and root litter substrates.

\section{Materials and methods}

\section{Study area and plant species}

We conducted litterbag experiments in two adjacent grazed and ungrazed sites located on a natural grassland at the centre of the Flooding Pampas in eastern Argentina $\left(36^{\circ} 30^{\prime} \mathrm{S}, 58^{\circ} 30^{\prime} \mathrm{W}\right)$. The area has a mean annual precipitation of $\sim 960 \mathrm{~mm}$ and a mean annual temperature of $14.9^{\circ} \mathrm{C}$; monthly temperatures vary from $8^{\circ} \mathrm{C}$ in July to $22^{\circ} \mathrm{C}$ in January. The landscape is extremely flat; soils are Typic Natraquols with a loamy A horizon $(\mathrm{pH}=6.7), 3.5 \%$ organic carbon, and $0.28 \%$ total nitrogen (Lavado and Taboada 1988; Chaneton and Lavado 1996). Flooding events occur almost annually during periods of heavy rainfall and may last for several weeks (Lavado and Taboada 1988). The local vegetation corresponds to a humid mesophytic grassland, the most widespread community type in the region (Perelman et al. 2001). The study area had been managed for cattle grazing at moderate stocking rates $\left(\sim 0.6\right.$ cow ha $\left.{ }^{-1} \mathrm{yr}^{-1}\right)$ for at least 50 years.

In this system, grazing exerts a major impact on grassland community structure (Soriano 1992; Rusch and Oesterheld 1997; Chaneton et al. 2002). Grazed communities may comprise up to 25 species $/ \mathrm{m}^{2}$ (total richness $\sim 60$ spp), while cattle exclusion decreases plant richness by almost 30\% (Chaneton et al. 2002; Semmartin et al. 2007). Grazing strongly alters energy and nutrient flows between vegetation and soil compartments (Doll 1991; Chaneton et al. 1996; Piñeiro et al. 2006). Nutrient budgets for grazed and ungrazed areas indicated that cattle grazing accelerates $\mathrm{N}$ and $\mathrm{P}$ cycling during the main growing season (Chaneton et al. 1996), which may be partly explained by grazing-induced changes in plant community composition (Semmartin et al. 2004; Garibaldi et al. 2007). Long-term cattle exclusion has shown that several grazing-tolerant grasses contribute substantially to community biomass both in grazed and ungrazed areas (Facelli 1988; Rusch and Oesterheld 1997). How these ubiquitous plant species respond to grazing history in terms of their litter functional attributes and likely influence on decomposition dynamics is virtually unknown (Semmartin and Ghersa 2006).

We focused on two grass species, L. multiflorum and P. dilatatum (hereafter named only by genus), which are highly palatable to cattle but maintain large viable populations in chronically grazed paddocks as well as in long-term ungrazed areas (Deregibus et al. 1994; Rusch and Oesterheld 1997). Lolium is a naturalised, $\mathrm{C}_{3}$ annual bunchgrass attaining its maximum biomass in late spring; Paspalum is a native, $\mathrm{C}_{4}$ perennial rhizomatous grass, with its peak biomass in summer. Both species exhibit substantial shoot plasticity and regrowth ability upon defoliation (Casal et al. 1987; Gibson et al. 1992; Loreti et al. 2001). Lolium populations regenerate every autumn from transient soil seed banks (Deregibus et al. 1994). Paspalum persists mainly through asexual growth of established ramets and relies on architectural plasticity for avoiding herbivory (Loreti et al. 2001). In the study area, Lolium accounts for about 8 and $48 \%$ of the total plant cover in grazed and ungrazed plots, respectively, while Paspalum represents about 3\% of the cover in both grazing conditions (Facelli 1988; Rusch and Oesterheld 1997; Semmartin et al. 2007).

Litter collection and experimental design

During July-September 2001 (mid winter-early spring), plants of both species were taken from two adjacent sites differing in grazing history. One site was grazed yearround at the nominal stocking rate, while the other was a 18 year-old, 4-ha exclosure protected from cattle 
grazing (hereafter 'grazed' and 'ungrazed' sites, respectively). Ten individuals of each species were dug out with a $30 \mathrm{~cm}$-deep soil core from the rooting zone and were transplanted to a common garden at the College of Agronomy campus in Buenos Aires, Argentina. Plants were grown in outdoor containers and watered as needed. After 3 weeks of acclimation, we proceeded to harvest all senescent aboveground material (leaves + stems, hereafter 'shoots') shed by the plants over a five-month period. A mix of living and dead root material (hereafter 'roots') was also collected during a final, destructive harvest. By using litter derived from plants grown under common conditions we reduced, but may have not fully eliminated, short-term effects on litter quality associated with recent grazing events. The litter material was washed, air-dried, cut into $2 \mathrm{~cm}$-long pieces and pooled according to species, tissue type and plant origin (grazed vs. ungrazed grassland). Litter bags $(6 \mathrm{~cm} \times 10 \mathrm{~cm})$ were made of $0.35 \mathrm{~mm}$-mesh nylon screen and filled with $1 \mathrm{~g}$ of air-dried litter.

Between 15 February and 9 July 2002 (mid summer through mid winter), we conducted parallel litterbag experiments at the two same sites from which the original plants had been collected. The grazed site was fenced for the duration of the experiment. In each site, the design comprised 8 litter substrates, resulting from 2 species (Lolium and Paspalum) $\times 2$ tissue types (shoots and roots) $\times 2$ origins (grazed and ungrazed), plus a control bag filled with plastic 'litter' (see below). Litterbags were collected after 45, 90 and 160 days of incubation, with five replicates per harvest date, for a total of 120 litterbags (plus five plastic controls) per incubation site. Within each site, litterbags were randomly distributed on a $36 \mathrm{~m}^{2}$ grid. Shoot litterbags were placed onto the soil surface, while root litterbags were buried $2 \mathrm{~cm}$ deep, horizontally, and covered with soil. Bags filled with plastic (non decomposable) 'litter' were included to test for inter-site differences in soil $\mathrm{N}$ availability in the absence of plant litter effects. To prevent root ingrowth, each bag was enclosed by a $15 \mathrm{~cm}$-diameter $\times$ $20 \mathrm{~cm}$-long PVC core sunk $18 \mathrm{~cm}$ deep; these cores were hand-weeded periodically. Three extra litterbags per substrate type were treated as described above, but were immediately retrieved to the laboratory and their dry weight used to adjust the initial litter mass for eventual manipulation losses. This material was also used for analyses of initial litter chemistry.

Two months before the experiment, all aerial vegetation was removed from each grid using a systemic herbicide (glyphosate, $0.6 \mathrm{~g} / \mathrm{m}^{2}$ ). Glyphosate effects on soil properties are usually negligible but may slightly stimulate soil microbial activity (Busse et al. 2001). Residual effects may be discarded since glyphosate undergoes rapid degradation or immobilisation in clayed soils (Busse et al. 2001; Araújo et al. 2003). This pre-treatment homogenised the grazed and ungrazed sites with regard to canopy-related microclimate conditions relevant to decomposition. Total rainfall during the experiment was $744 \mathrm{~mm}(66 \%$ above a 45 -year average). As a result, the study area became flooded in the end of March 2002 and remained so until the end of the experiment. The grazed and ungrazed sites were similarly waterlogged with 3-10 cm standing water. Flooding alters soil nutrient dynamics (Ponnamperuma 1984) and therefore our findings should be interpreted with this environmental setting in mind.

\section{Litter and soil analyses}

After each harvest, litter was carefully brushed, washed, air-dried to constant weight, and weighed to determine the mass remaining. Nitrogen $(\mathrm{N})$, phosphorus $(\mathrm{P})$, cell solubles, celluloses (cellulose + hemicellulose) and lignin concentrations, and the lignin: $\mathrm{N}$ ratio, were determined to characterise initial 'quality' for each litter type. Nutrient concentrations were also determined for the litter remaining in each harvest date. Litter $\mathrm{N}$ and $\mathrm{P}$ concentrations were obtained using standard Kjeldahl acid digestions and were colorimetrically assayed in an Alpkem (Wilsonville, OR, USA) autoanalyzer. Fibre determinations followed the Van Soest et al. (1991) procedure. Changes in litter $\mathrm{N}$ and $\mathrm{P}$ contents were calculated by multiplying the remnant litter mass by the corresponding nutrient concentrations; data were expressed as percentages of the initial $\mathrm{N}$ and $\mathrm{P}$ contents. Soil $\mathrm{N}$ availability was measured beneath each litterbag ( $2 \mathrm{~cm}$ depth) after 45 days of incubation. Since the study area became flooded in late March ( day 40), measurements were discontinued thereafter. Soil mineral $\mathrm{N}$ was extracted with a $2 \mathrm{~mol} / \mathrm{L} \mathrm{KCl}$ solution and colorimetrically assayed for ammonium and nitrate concentrations (Alpkem autoanalyser).

Data analysis

Overall differences in initial litter chemistry were examined using multivariate analysis of variance 
(MANOVA) testing for effects of tissue type, species and origin of litter, followed by univariate ANOVAs performed on each dependent variable. Changes in litter mass remaining and in litter $\mathrm{N}$ and $\mathrm{P}$ content during decomposition were examined through four-way ANOVAs. Since shoot and root litterbags were placed in different positions, absolute differences between above- and belowground litter decomposition may not be strictly comparable (Gholz et al. 2000). Thus, analyses were performed separately for shoot and root substrates, with species, litter origin, incubation site and harvest date as main factors. Although ANOVA models included all higher-order interactions, we focused on interaction terms implying a grazing history effect on decomposition, either through litter origin or incubation site. Soil mineral $\mathrm{N}$ was first evaluated by a two-way ANOVA testing for effects of incubation site and harvest date ( 0 vs. 45 days) on soil $\mathrm{N}$ measured beneath control (plastic litter) bags. In addition, differences in soil $\mathrm{N}$ availability associated with litter decomposition patterns were examined for shoot and root litters using separate three-way ANOVAs, with species, litter origin and incubation site as main factors. Tukey tests $(P<0.05)$ were used for post-hoc multiple comparisons among treatments. Note that in all analyses the incubation site effects were based on one location per grazing condition, meaning that statistical differences between sites cannot be unequivocally attributed to prior grazing management. However, when a significant site effect was found, we relied on the fact that, before grazing was excluded in 1983, the study sites could not be distinguished with regard to plant community, soil type or flooding regime.

\section{Results}

Initial litter chemistry

Multivariate ANOVA indicated that tissue type, species and their interaction accounted for most variation in initial litter chemistry (Table 1). Roots generally contained more lignin and had higher lignin: $\mathrm{N}$ ratios than shoots (Table 2). Lolium litter types had higher nutrient and cell soluble contents, and lower celluloses and lignin: $\mathrm{N}$ ratios, than Paspalum ones (Tables 1,2). Litter origin had a relatively small but significant overall effect on litter quality $(P<0.05$, Wilk's lambda). Univariate tests revealed that grazing (origin) effects on individual chemical traits largely depended on tissue type and marginally on the grass species (Table 1). Irrespective of species, plants from the grazed site produced shoots with higher cell solubles content and lower lignin: $\mathrm{N}$ ratios than those from the ungrazed site, whereas the opposite pattern was found in roots $\left(P_{\text {tissue }} \times\right.$ origin $=0.04$; Table 2$)$. In addition, Lolium plants from the grazed site shed litter with a higher $\mathrm{N}$ content than conspecifics from the ungrazed site, whereas Paspalum litter showed the opposite trend $\left(P_{\text {species } \times \text { origin }}=0.052\right.$; Table 2$)$.

\section{Litter decomposition}

In preliminary analyses including all four experimental factors, shoots decomposed much faster than roots irrespective of species, litter origin and incubation site (four-way ANOVA, $P<0.0001$ ). After 160 days, litter mass remaining ranged $20-75 \%$ and $73-96 \%$, for shoots and roots, respectively (Fig. 1). Hence, we carried out separate analyses for each tissue type. Shoot litter decomposition depended strongly on the species and incubation site (Table 3). Lolium shoots decomposed faster than Paspalum shoots, and shoots incubated in the grazed site decomposed $\sim 20 \%$ faster than those in the ungrazed site (Fig. 1, upper panels). The litter origin further affected patterns of mass loss in shoots but not roots (Table 3). Shoots produced by Lolium plants taken from the grazed site decomposed slightly, but significantly, faster than those from the ungrazed site, yet only when incubated in the grazed site. In contrast, no significant effect of grazing origin was detected for Paspalum shoots $\left(P_{\text {species }} \times\right.$ origin $\times$ site $=$ 0.015; Fig. 1). Root mass loss differed between species, with Lolium roots decomposing faster than Paspalum ones, irrespective of litter origin and incubation site (Table 3; Fig. 1, lower panels).

Nutrient dynamics in litter and soil

Species, origin of litter and incubation site interactively influenced $\mathrm{N}$ and $\mathrm{P}$ dynamics during litter breakdown (Table 3). Lolium shoots released N and P faster than Paspalum shoots which, in turn, tended to immobilise both nutrients. This species-specific pattern was most evident for shoot litter shed by plants originary from the grazed site $\left(P_{\text {species }} \times\right.$ origin $<0.0005$; Figs. 2, 3). Furthermore, rates of $\mathrm{N}$ and $\mathrm{P}$ release from decomposing shoots were faster in the grazed site $\left(P_{\text {site }} \times\right.$ harvest $=$ 
Table 1 MANOVA (Wilk's $\lambda$ ) and ANOVA ( $F$ values) results for the initial chemistry of Lolium and Paspalum litter types

\begin{tabular}{|c|c|c|c|c|c|c|c|}
\hline \multirow[t]{2}{*}{ Source } & \multirow{2}{*}{$\frac{\text { MANOVA }}{\text { Wilk's } \lambda}$} & \multicolumn{6}{|c|}{ Univariate ANOVAs } \\
\hline & & Nitrogen & Phosphorus & Solubles & Celluloses & Lignin & Lignin: $\mathrm{N}$ \\
\hline Tissue & $0.20 * * *$ & $5.64 * *$ & 0.83 & $17.7 * * *$ & 0.08 & $14.8 * * *$ & $9.56 * *$ \\
\hline Species & $0.15^{* * *}$ & $29.1 * * * *$ & $10.94 * * *$ & $22.2 * * *$ & $8.16^{* * *}$ & 2.82 & $12.9 * * *$ \\
\hline Origin & $\mathbf{0 . 3 3} * *$ & 0.61 & 2.12 & $3.31 *$ & 0.04 & 0.96 & 0.02 \\
\hline Tissue $\times$ Species & $0.27 * *$ & $5.61 * *$ & 0.77 & 1.3 & 0.05 & 0.92 & $6.88 * *$ \\
\hline Species $\times$ Origin & 0.52 & $4.42 *$ & 0.06 & 0.04 & 0.93 & 0.05 & 1.66 \\
\hline Tissue $\times$ Origin & $0.43 *$ & 1.18 & 0.06 & $12.41 * * *$ & 0.24 & 1.36 & $4.82 * *$ \\
\hline Tissue $\times$ Species $\times$ Origin & 0.57 & 0.71 & 2.28 & 0.33 & 0.10 & 0.97 & 0.81 \\
\hline
\end{tabular}

$* * * * P<0.001, * * * P<0.01, * * P<0.05, * P<0.10$

For all effects, degrees of freedom were 5 and 12 (multivariate test), and 1 and 16 (univariate tests). Effects associated with litter origin (i.e., litter produced by plants from grazed vs. ungrazed sites) are shown in bold.

0.0002), where interspecific differences increased significantly over time $\left(P_{\text {species }} \times\right.$ site $\times$ harvest $<0.005$; Figs. 2, 3). Root nutrient dynamics did not differ between incubation sites and mostly reflected litter species $\times$ origin interactions, which depended on the nutrient considered (Table 3). In general, $\mathrm{N}$ was retained by decomposing roots but this effect was greater for Paspalum roots from the grazed origin. In contrast, $\mathrm{P}$ tended to be released from roots, although it was retained by Lolium roots from the grazed origin (Figs. 2, 3).

Soil $\mathrm{N}$ availability beneath control (plastic litter) bags at 0 and 45 days of incubation was, on average, higher in the grazed than in the ungrazed site $(41.5 \mathrm{vs}$. $12.2 \mu \mathrm{g} \mathrm{N} \mathrm{g}^{-1}$ soil, respectively; $\left.F_{1,26}=12.8, P=0.0014\right)$ and did not differ between dates $\left(P_{\text {date }}=0.30 ; P_{\text {site } \times \text { date }}=\right.$ $0.35)$. The same pattern was found after 45 days of incubation for soil mineral $\mathrm{N}$ measured beneath plant litter bags (three-way ANOVA, site effect: shoots, $F_{1,32}=30.7, P<0.0001$; roots, $F_{1,32}=31.1, P<0.0001$;
Fig. 4). In addition, soil $\mathrm{N}$ levels beneath litterbags were affected by a weakly significant, species $\times$ origin $\times$ site interaction (shoots, $F_{1}, 32=4.7, P=0.038$; roots, $F_{1,32}=4.22, P=0.048$; all other effects $P>0.10$ ). This likely reflected idiosyncratic differences among microsites amended with either Lolium or Paspalum litter substrates. Yet, no consistent effects of shoot or root litter origin were detected on soil $\mathrm{N}$ levels in grazed or ungrazed grassland ( $P>0.05$, Tukey tests; Fig. 4).

\section{Discussion}

Large grazers have been shown to influence nutrient cycling through their effects on the quality of litter produced by grazing-tolerant species and the site conditions for decomposition (Holland et al. 1992; Bardgett et al. 1998; Sankaran and Augustine 2004). Yet how these two mechanisms act together affecting above- and belowground litter decomposition within

Table 2 Initial chemical attributes of shoot and root litter produced by Lolium and Paspalum plants collected from nearby grazed (G) and ungrazed (U) sites in the Flooding Pampa, Argentina

\begin{tabular}{|c|c|c|c|c|c|c|c|c|}
\hline Species & Tissue & Origin & Nitrogen $(\%)$ & Phosphorus (\%) & Solubles $(\%)$ & Cellulose $(\%)$ & Lignin $(\%)$ & Lignin: $\mathrm{N}$ \\
\hline \multirow[t]{4}{*}{ Lolium } & \multirow[t]{2}{*}{ Shoots } & $\mathrm{U}$ & $0.79(0.06)$ & $0.08(0.003)$ & $25.5(1.8)$ & $62.4(2.1)$ & $9.5(3.4)$ & $12.7(4.8)$ \\
\hline & & G & $0.88(0.16)$ & $0.08(0.01)$ & $32.5(1.9)$ & $61.7(0.4)$ & $5.5(0.9)$ & $6.4(0.4)$ \\
\hline & \multirow[t]{2}{*}{ Roots } & $\mathrm{U}$ & $1.07(0.04)$ & $0.10(0.007)$ & $24.0(1.2)$ & $64.0(2.8)$ & $10.6(0.6)$ & $9.9(0.8)$ \\
\hline & & G & $1.13(0.05)$ & $0.08(0.01)$ & $21.7(0.3)$ & $59.9(3.2)$ & $12.5(2.8)$ & $10.9(1.9)$ \\
\hline \multirow[t]{4}{*}{ Paspalum } & \multirow[t]{2}{*}{ Shoots } & $\mathrm{U}$ & $0.69(0.08)$ & $0.07(0.001)$ & $19.7(2.6)$ & $67.5(5.7)$ & $8.3(1.9)$ & $12.6(2.4)$ \\
\hline & & G & $0.64(0.04)$ & $0.05(0.008)$ & $24.9(0.5)$ & $69.5(0.6)$ & $6.4(0.1)$ & $10.2(0.7)$ \\
\hline & \multirow[t]{2}{*}{ Roots } & $\mathrm{U}$ & $0.80(0.07)$ & $0.06(0.005)$ & $19.6(2.7)$ & $66.8(1.9)$ & $14.8(2.4)$ & $18.7(3.4)$ \\
\hline & & $\mathrm{G}$ & $0.53(0.02)$ & $0.06(0.016)$ & $18.0(0.6)$ & $68.0(3.2)$ & $13.3(1.2)$ & $25.5(3.3)$ \\
\hline
\end{tabular}

Data show means, with standard errors in parentheses $(n=3)$. 
Fig. 1 Changes in litter mass remaining for shoots and roots produced by Lolium and Paspalum plants from grazed and ungrazed grassland (litter origin), when reciprocally incubated in grazed (a) and ungrazed (b) sites. Data are means \pm 1 SE $(n=5)$; full statistics are shown in Table 3

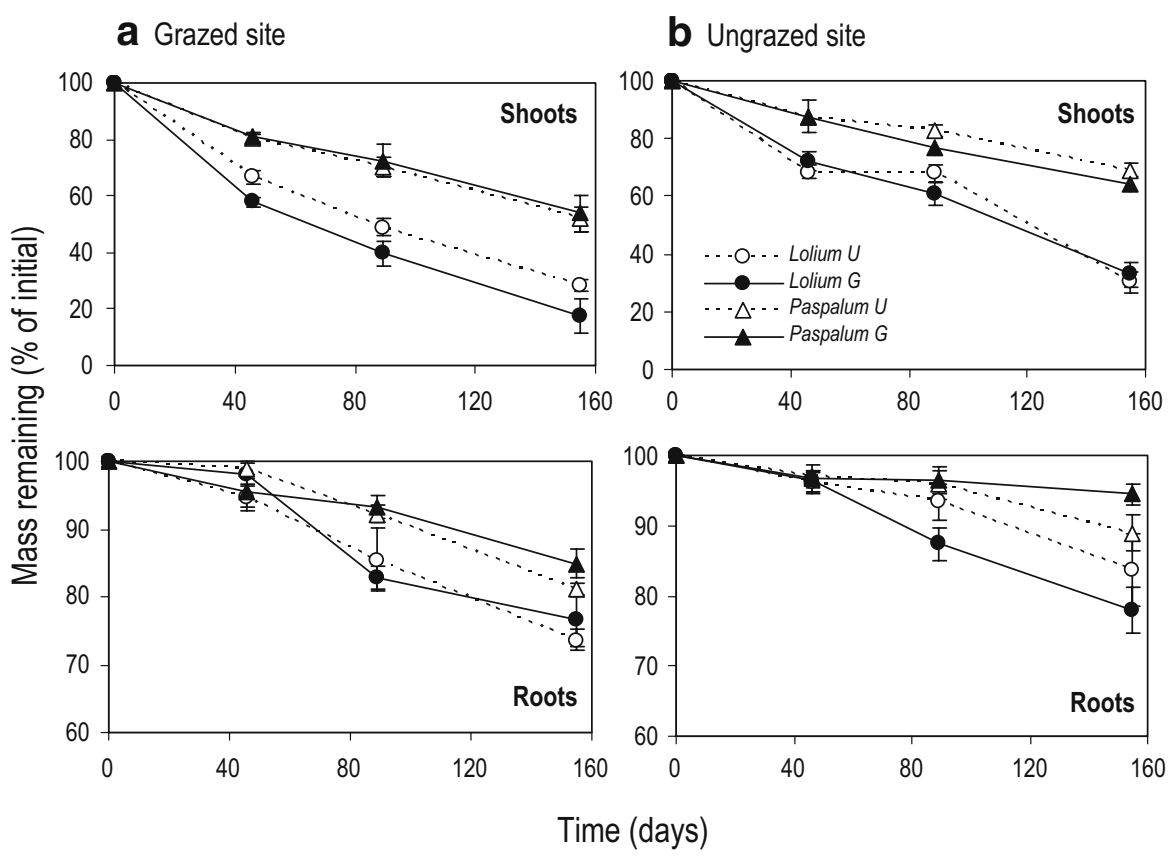

the same system has remained largely untested. Our results suggest that, in this flood-prone grassland, grazing affected nutrient cycling by changing both the soil environment for decomposition, and the chemical composition and decomposition dynamics of litter derived from two grass species. The latter ('origin') effect indicates that the grazing condition experienced by the plants influenced their subsequent decomposition and nutrient turnover upon tissue senescence. Further, we found that grazing effects on decomposi-

Table 3 ANOVA results ( $F$ values) for changes in the litter mass, and nitrogen and phosphorous contents remaining at three harvest dates during decomposition of Lolium and Paspalum litter substrates incubated in nearby grazed and ungrazed sites

\begin{tabular}{|c|c|c|c|c|c|c|c|}
\hline \multirow[t]{2}{*}{ Source } & \multirow[t]{2}{*}{ df } & \multicolumn{3}{|c|}{ Shoot litter } & \multicolumn{3}{|c|}{ Root litter } \\
\hline & & Mass & Nitrogen & Phosphorus & Mass & Nitrogen & Phosphorus \\
\hline Species (Sp) & 1 & $256.7^{* * *}$ & $220.4^{* * *}$ & $126.3^{* * *}$ & $18.0^{* * *}$ & $18.6^{* * *}$ & $12.7^{* * *}$ \\
\hline Origin (Or) & 1 & $4.1^{*}$ & 0.9 & $19.5^{* * *}$ & 0.7 & $30.6^{* * *}$ & $14.2^{* * *}$ \\
\hline Incubation site (Site) & 1 & $54.9^{* * *}$ & $23.9^{* * *}$ & 0.0 & 2.3 & 1.5 & 0.1 \\
\hline Harvest $(\mathrm{H})$ & 2 & $157.5^{* * *}$ & $46.1^{* * * *}$ & $25.9^{* * *}$ & $30.6^{* * *}$ & $32.6^{* * *}$ & $54.2^{* * *}$ \\
\hline $\mathrm{Sp} \times \mathrm{Or}$ & 1 & 1.7 & $12.9^{* * *}$ & $30.7^{* * *}$ & 0.1 & $26.0^{* * *}$ & $65.4^{* * *}$ \\
\hline $\mathrm{Sp} \times$ Site & 1 & 0.7 & 1.9 & $7.3^{* *}$ & 0.7 & 0.6 & 1.8 \\
\hline Or $\times$ Site & 1 & 0.5 & 0.2 & 0.2 & 0.2 & 0.8 & 0.2 \\
\hline $\mathrm{Sp} \times \mathrm{H}$ & 2 & $9.0^{* * *}$ & $17.9^{* * *}$ & $9.4^{* * *}$ & $4.6^{*}$ & 0.2 & 0.7 \\
\hline $\mathrm{Or} \times \mathrm{H}$ & 2 & 0.6 & 0.5 & 0.5 & 1.8 & 1.1 & 0.1 \\
\hline Site $\times H$ & 2 & 1.7 & $9.2^{* * *}$ & $9.2^{* * * *}$ & 0.8 & 0.6 & 0.2 \\
\hline $\mathrm{Sp} \times \mathrm{Or} \times$ Site & 1 & $6.1^{*}$ & 3.7 & 2.9 & 0.0 & 3.8 & 0.4 \\
\hline $\mathrm{Sp} \times \mathrm{Or} \times \mathrm{H}$ & 2 & 0.1 & 1.9 & 1.2 & 0.7 & 0.2 & 0.6 \\
\hline $\mathrm{Sp} \times$ Site $\times \mathrm{H}$ & 2 & 2.8 & $10.3^{* * *}$ & $5.5^{* *}$ & 1.6 & 0.4 & 0.2 \\
\hline Or $\times$ Site $\times H$ & 2 & 0.8 & $3.6^{*}$ & 0.7 & 0.3 & 0.1 & 0.2 \\
\hline $\mathrm{Sp} \times$ Or $\times$ Site $\times \mathrm{H}$ & 2 & 0.2 & 0.1 & 0.1 & 0.3 & 1.4 & 0.1 \\
\hline
\end{tabular}

$* * * P<0.001, * * P<0.01, * P<0.05$

Litter was produced by plants from grazed or ungrazed grassland ('origin'). Effects associated with grazing history (litter origin and incubation site) are shown in bold. Error term $\mathrm{df}=96$. 
Fig. 2 Nitrogen dynamics in shoot and root litter produced by Lolium and Paspalum plants from grazed and ungrazed grassland (litter origin), when reciprocally incubated in grazed (a) and ungrazed (b) sites. Data are means \pm 1 SE $(n=5)$; full statistics are shown in Table 3

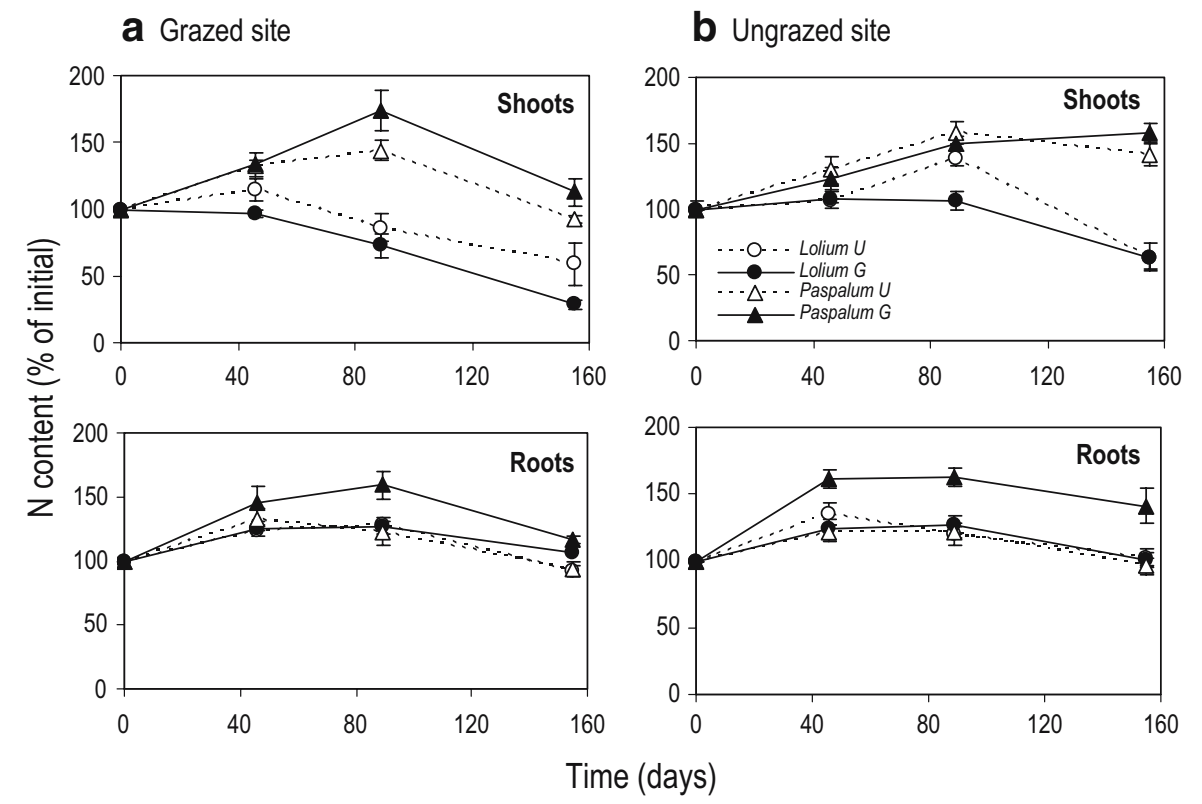

tion, either plant or soil mediated, mostly involved shoot-derived litter rather than the more recalcitrant, root litter compartment. Whether grazing origin accelerated or retarded shoot decomposition depended on the species. Most importantly, however, shoot decomposition and nutrient release were generally faster in the grazed grassland, which contained higher levels of soil available $\mathrm{N}$ than the ungrazed grassland.

In general, grazing effects on decomposition were stronger for shoot than for root litter substrates. Mass loss and nutrient $(\mathrm{N}, \mathrm{P})$ release from decomposing shoots were singly or interactively affected by litter origin and incubation site, indicating a role for grazing history in controlling current decomposition processes at the soil surface. In contrast, root decomposition resulted similar in grazed and ungrazed soils, while grazing effects on root $\mathrm{N}$ and $\mathrm{P}$ turnover mediated by plant origin were inconsistent, as they depended on the nutrient and species considered (Table 3, Figs. 2, 3). The absence of a clear belowground decomposition
Fig. 3 Phosphorus dynamics in shoot and root litter produced by Lolium and Paspalum plants from grazed and ungrazed grassland (litter origin), when reciprocally incubated in grazed (a) and ungrazed (b) sites. Data are means \pm 1 SE $(n=5)$; full statistics are shown in Table 3

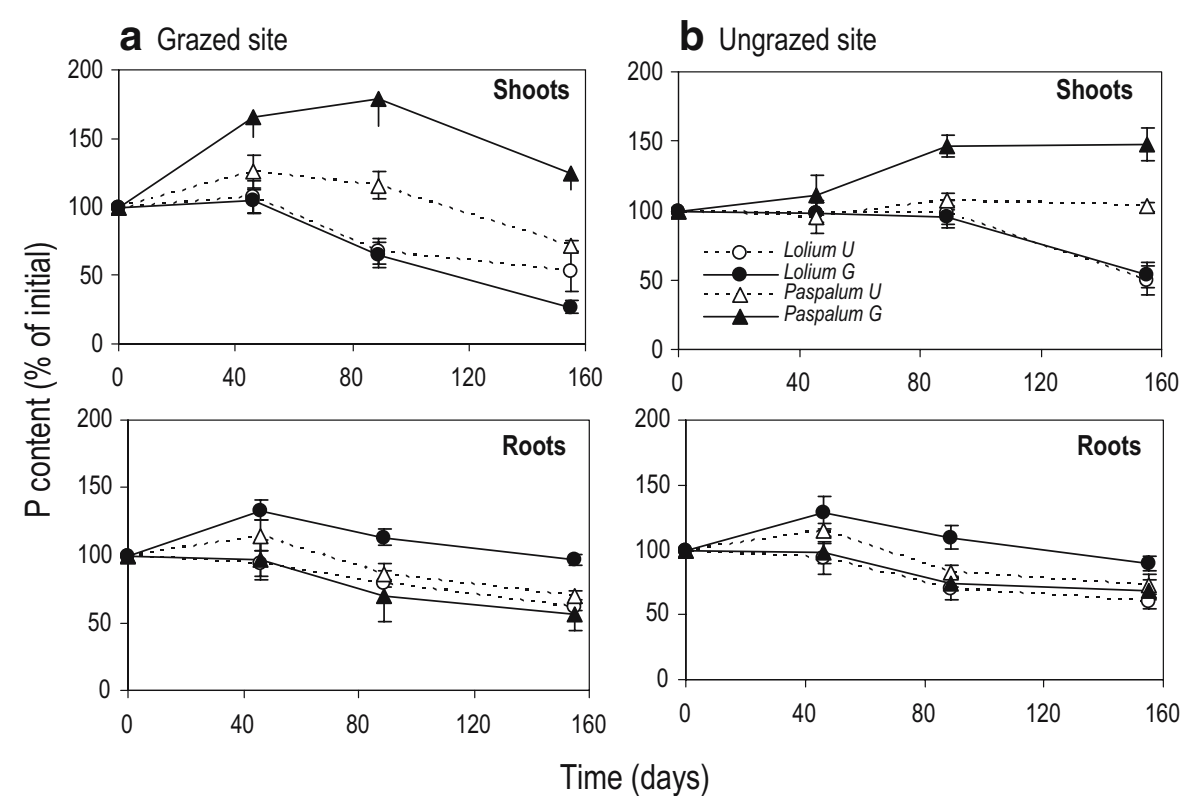




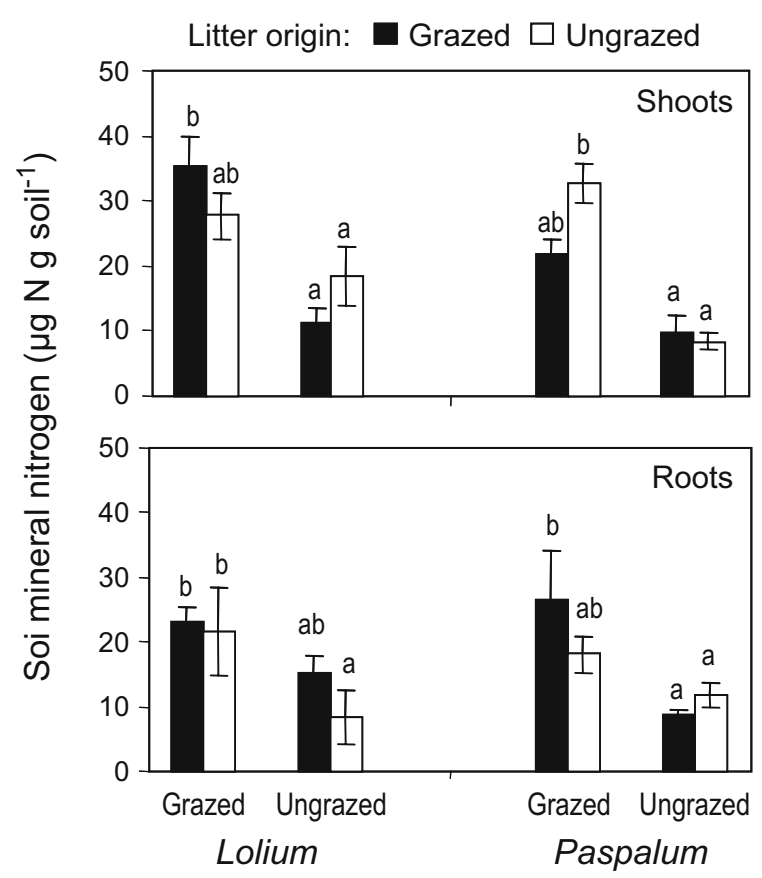

Fig. 4 Soil mineral nitrogen $\left(\mathrm{NH}_{4}^{+}+\mathrm{NO}_{3}^{-}\right)$beneath shoot (upper panel) and root (lower panel) litter bags of Lolium and Paspalum plants from grazed and ungrazed grassland (origin: solid vs. empty bars), decomposing in grazed and ungrazed sites (indicated on the $x$ axis). Soil $\mathrm{N}$ levels measured after 45 days of litter incubation. Bars show means \pm 1 SE $(n=5)$. Letters above bars indicate significant differences across treatments within panels $(P<0.05)$

response to grazing coincided with the fact that, overall, root substrates decomposed more slowly than shoots (Biondini and Manske 1996; Gholz et al. 2000; Vivanco and Austin 2006). A comparable pattern was reported by Moretto et al. (2001) for a semiarid grassland. These authors found that shoot litter from palatable grasses decomposed twice as fast as that from unpalatable grasses, although root decomposition rates did not differ between both types of grasses (Moretto et al. 2001). In our study, roots had higher lignin contents and lignin: $\mathrm{N}$ ratios than shoots, which could account for their lower decomposibility (Fig. 1). Moreover, relative to shoots, root litter exhibited little variation in initial chemistry in relation to grazing origin (Table 2), a pattern previously found across a range of species from contrasting grassland systems (Semmartin et al. 2004). On the other hand, roots from the grazed site had lower cell solubles and higher lignin: $\mathrm{N}$ ratios than plants from the ungrazed site. Although such attributes often correlate negatively with decomposition rates (Silver and Miya 2001; Semmartin et al. 2004), in our case they did not mediate a predictable influence of grazing origin on root decomposition. Alternatively, it might be that the sub-surface soil layer where roots decompose provides a more constant microenvironment that veils the potential influence of litter quality on decomposition (Gholz et al. 2000). It thus appears that grazing history had little impact on belowground litter functioning in the study grasses (cf. Holland and Detling 1990). This finding is mostly relevant to grassland ecosystems, where a major part of the carbon fixed is driven to belowground organs (Piñeiro et al. 2006), and where long-term grazing may have variable impacts on root production (Doll 1991; McNaughton et al. 1998; Frank et al. 2002; Sankaran and Augustine 2004; Semmartin et al. 2007). More work on root litter decomposition across grazing gradients is needed to fully understand the effects of large herbivores on soil carbon and nutrient cycling.

We detected significant grazing effects on shoot litter decomposition associated with plant origin (i.e., whether from grazed or ungrazed grassland), even though the litter we used in the incubations was produced under common growing conditions. This suggests that grazing history shaped, either directly through defoliation or indirectly via changed site conditions, some intrinsic functional traits of these grass species evidenced during the early stages of litter decomposition. Several studies have documented differences in decomposition associated with differences in grazing/browsing resistance among plant species (Pastor et al. 1993; Olofsson and Oksanen 2002; Wardle et al. 2002; Garibaldi et al. 2007). In contrast, how grazing modifies decomposition dynamics within grazing-tolerant species (Holland et al. 1992; Bardgett et al. 1998) is still not well understood, although both mechanisms may contribute to overall grazing impacts on nutrient cycling (Bardgett and Wardle 2003). It is possible that long-term grazing has selected for certain grass genotypes that are somehow more resistant to defoliation, and also produce a different type of litter with the potential to alter decomposition and nutrient cycling (Holland and Detling 1990). Such indirect effects of plant genotypic variation on ecosystem-level processes have been recently documented for various systems with insect herbivory (Madritch and Hunter 2002; Chapman et al. 2003; Schweitzer et al. 2005).

We found that plants from the grazed site produced litter with lower fibre content (higher cell solubles) and lignin: $\mathrm{N}$ ratios than those from the ungrazed site, 
which likely contributed to accelerate their decomposition (Aber and Melillo 1991; Vivanco and Austin 2006). Nevertheless, the nature of grazing effects on decomposition through the litter 'origin' depended on the grass species. Whereas Lolium shoots from the grazed site had greater $\mathrm{N}$ contents, and decomposed and released $\mathrm{N}$ faster than their counterparts from the ungrazed site, Paspalum shoots from the grazed site showed the opposite trends, retaining more $\mathrm{N}$ and $\mathrm{P}$ during breakdown. Lolium shoots from the grazed site decomposed even faster when incubated in their site of origin, suggesting that grazing induced changes at the whole plant level and in the soil environment that acted synergistically enhancing litter breakdown in this $\mathrm{C}_{3}$ grass (see also Olofsson and Oksanen 2002). Our results for Lolium reinforce previous work conducted at the community level in this grassland (Semmartin et al. 2004; Garibaldi et al. 2007), where grazing-promoted species decomposed more rapidly than grazing-reduced species.

Despite both study grasses being regarded as grazing tolerant species, we observed contrasting, species-specific effects of grazing origin on initial shoot chemistry and nutrient turnover, which amplified intrinsic functional differences between them (Figs. 2, 3). The lack of a consistent response to grazing may seem unsurprising given that the study species differed with regard to life history, growth form and photosynthetic metabolism (see Materials and methods). Yet, how such primary traits might have determined divergent responses to grazing history in terms of litter quality and decomposition is not clear. The limited evidence on this topic suggests that idiosyncratic, intraspecific changes in litter decomposition as a function of prior grazing may be the norm (Ruess and McNaughton 1987; Jaramillo and Detling 1988; Polley and Detling 1988; Holland et al. 1992; Smith 1998; Semmartin et al. 2004). Understanding what traits determine the 'afterlife' plant functional responses to grazing at the within-species level would require comparative analyses using a larger set of litter species, something that has yet to be done for any ecosystem. Interestingly, however, our results for shoot and root substrates show that grazing not only increased differences in decomposition dynamics between species but also between above- and belowground litter pools. Thus, a greater small-scale heterogeneity in nutrient cycling processes may be expected within grazed grasslands.
The aforementioned effects of grazing origin on litter decomposition did not translate into consistent differences in soil $\mathrm{N}$ levels beneath litter bags, except for the generally higher soil mineral $\mathrm{N}$ measured in shoot than in root amended microsites (Fig. 4). We suggest this result may have partly reflected the influence of soil waterlogging on mineral $\mathrm{N}$ pools during the experiment (Ponnamperuma 1984). In particular, flooding conceivably increased denitrification during the summer (Murray et al. 2004; Wrage et al. 2004). Together with the horizontal movement of nutrients dissolved in standing water, gaseous $\mathrm{N}$ losses would have contributed to offset any smallscale differences in soil mineral $\mathrm{N}$ derived from decomposition of various litter types (see Fig. 4). In addition, under flooding conditions, $\mathrm{N}$ being released from decomposing litter may be rapidly taken up by soil microbes close to the soil surface (Ponnamperuma 1984), thus precluding any pattern in soil $\mathrm{N}$ availability beneath litterbags. On the other hand, while soil waterlogging may constrain litter decomposition by reducing oxygen supply to microorganisms (Haynes 1986), it is clear from our results (Figs. 1, 2 and 3) that prolonged flooding did not override differences in grass litter dynamics attributable to prior grazing history. In particular, patterns of decomposition documented during the first month of incubation (non-flooded soil) persisted for the remaining of the experiment (flooded soil). Since the study grassland typically undergoes periodical flooding, and litterbags were submerged for most of the experiment, we suggest that our results may be mostly relevant to understand grazing effects on litter breakdown in flood-prone ecosystems.

In this study, the most consistent influence of grazing history on aboveground litter decomposition was associated with the incubation site, and generally implied an acceleration of shoot mass loss and nutrient release. Notice that marked differences in decomposition between grazed and ungrazed sites occurred even though the whole study area remained waterlogged for more than 3 months (see Fig. 4). Because the potential influence of canopy microclimate on soil surface processes was removed, we discard differences in incident radiation, soil temperature and moisture as driving factors (Shariff et al. 1994; Bardgett et al. 1998). If, however, grazed vs. ungrazed sites with intact vegetation had been compared, we suspect that observed differences in litter decomposition might 
have been even stronger, as decreased light penetration and soil temperatures below the ungrazed canopy (Semmartin and Oesterheld 2001) would have further reduced decomposer activity inside the exclosure. Alternatively, it is plausible that long-term cattle grazing had modified the soil environment for decomposition. Indeed, faster litter breakdown in the grazed site corresponded with higher standing levels of soil available $\mathrm{N}$, which may reflect greater nutrient returns in animal faeces, deposition of readily decomposable plant litter, and higher net mineralisation rates (Seagle and McNaughton 1992; Chaneton et al. 1996; McNaughton et al. 1997; Tracy and Frank 1998). Nitrogen availability has been shown to enhance decomposer activity in fertilization experiments (Kemp et al. 1994; Knorr et al. 2005), especially where productivity is co-limited by $\mathrm{N}$ and $\mathrm{P}$ as in the study grassland (Semmartin et al. 2007). While the precise mechanisms are beyond the scope of this study, based on evidence from other systems, we hypothesise that changes in the soil microbial community might be involved in the observed differences in shoot litter turnover between grazed and ungrazed sites (Bardgett et al. 1998, 2001).

In conclusion, we have shown that the influence of large herbivores on decomposition processes induced through site conditions was more consistent than that mediated by the quality of litter shed by two grazingtolerant grasses. Aboveground litter release of $\mathrm{N}$ and $\mathrm{P}$ was stimulated in grazed grassland irrespective of litter species and origin, suggesting that the soil environment outweighed litter chemical attributes as a control of decomposition in this system. As predicted by current models (e.g. Bardgett and Wardle 2003), grazing effects on nutrient cycling mediated by litter quality changes did occur but were idiosyncratic for two co-occurring grasses. We showed that, at the intraspecific level, prior grazing can either enhance or retard shoot litter decomposition and nutrient mineralisation. Such species-specific effects of grazing on litter functional attributes might relate to the photosynthetic metabolism $\left(\mathrm{C}_{3}\right.$ vs $\mathrm{C}_{4}$, see Kemp et al. 1994) and $\mathrm{N}$ economy of the plants involved, a proposal that needs further investigation. In contrast, we provided strong evidence that grazing history exerted no apparent effect on nutrient cycling through root litter pools. This finding (see also Biondini and Manske 1996; Moretto et al. 2001) makes it clear that care must be taken when modeling belowground litter compartments to explore grazing impacts on carbon and nutrient cycling at the whole ecosystem level.

Acknowledgements We thank the owners of Estancia "Las Chilcas" for allowing us to work on their property. This study was supported by grants from Agencia Nacional de Promoción Científica y Tecnológica (Project 6761) and Universidad de Buenos Aires (Project G413), and Fundación Antorchas and René Baron Fellowships.

\section{References}

Aber JD, Melillo JM (1991) Litter decomposition and nutrient balances. In: Terrestrial ecosystems. Saunders College Publishing, Philadelphia, pp 173-192

Araújo ASF, Monteiro RTR, Abarkeli RB (2003) Effect of glyphosate on the microbial activity of two Brazilian soils. Chemosphere 52:799-804

Bardgett RD, Wardle DA, Yeates GW (1998) Linking aboveground and below-ground interactions: how plant responses to foliar herbivory influence soil organisms. Soil Biol Biochem 30:1867-1878

Bardgett RD, Jones AC, Jones DL, Kemmitt SJ, Cook R, Hobbs PJ (2001) Soil microbial community patterns related to the history and intensity of grazing in submontane ecosystems. Soil Biol Biochem 33:1653-1664

Bardgett RD, Wardle DA (2003) Herbivore-mediated linkages between aboveground and belowground communities. Ecology 89:2258-2268

Biondini ME, Manske L (1996) Grazing frequency and ecosystem processes in a northern mixed prairie, USA. Ecol Appl 6:239-256

Busse MD, Ratcliff AW, Shestak CJ, Powers RF (2001) Glyphosate toxicity and the effects of long-term vegetation control on soil microbial communities. Soil Biol Biochem 33:1777-1789

Casal JJ, Sanchez RA, Deregibus VA (1987) The effect of light quality on shoot extension growth in three species of grasses. Ann Bot 59:1-7

Chaneton E, Lavado RS (1996) Soil nutrients and salinity after long-term grazing exclusion. J Range Manag 41:182-187

Chaneton EJ, Lemcoff JH, Lavado RS (1996) Nitrogen and phosphorus cycling in grazed and ungrazed plots in a temperate subhumid grassland in Argentina. J Appl Ecol 33:291-302

Chaneton EJ, Perelman SB, Omacini M, León RJC (2002) Grazing, environmental heterogeneity, and alien plant invasions in temperate grasslands. Biological Invasions 4:7-24

Chapman SK, Hart S, Cobb NS, Whitham TG, Koch GW (2003) Insect herbivory increases litter quality and decomposition: an extension of the acceleration hypothesis. Ecology 84:2867-2876

Coughenour MB, McNaughton SJ, Wallace LL (1985) Shoot growth and morphometric analyses of Serengeti graminoids. Afr J Ecol 23:179-194

De Mazancourt C, Loreau M, Abbadie L (1998) Grazing optimization and nutrient cycling: when do herbivores enhance plant production? Ecology 79:2242-2252 
Deregibus VA, Casal JJ, Jacobo EJ, Gibson D, Kauffman M (1994) Evidence that heavy grazing may promote the germination of Lolium multiflorum seeds via phytochromemediated perception of high red/far-red ratios. Funct Ecol 8:536-542

Doll U (1991) C-14 translocation to the below ground subsystem in a temperate humid grassland (Argentina). In: McMichael B, Persson H (eds) Plant roots and their environment. Elsevier, Amsterdam, pp 350-358

Dyer MI, Acra MA, Wang GM, Coleman DC, Freckman DW, McNaughton SJ, Strain BR (1991) Source-sink carbon relations in two Panicum coloratum ecotypes in response to herbivory. Ecology 72:1472-1483

Facelli J (1988) Response to grazing after nine years of cattle exclusion in a Flooding Pampa grassland. Vegetatio $78: 21-25$

Frank DA, Kuns MM, Guido DR (2002) Consumer control of grassland plant production. Ecology 83:602-606

Garibaldi LA, Semmartin M, Chaneton EJ (2007) Grazinginduced changes in plant composition affect litter quality and nutrient cycling in Flooding Pampa grasslands. Oecologia 151:650-662

Gholz HL, Wedin DA, Smitherman SM, Harmon ME, Parton WJ (2000) Long-term dynamics of pine and hardwood litter in contrasting environments: toward a global model of decomposition. Glob Chang Biol 6:751-765

Gibson D, Casal JJ, Deregibus VA (1992) The effects of plant density on shoot and leaf lamina angles in Lolium multiflorum and Paspalum dilatatum. Ann Bot 70:69-73

Grayston SJ, Campbell CD, Bardgett RD, Mawdsley JL, Clegg CD, Ritz K, Griffiths BS, Rodwell JS, Edwards SJ, Davies WJ, Elston DJ (2004) Assessing shifts in soil microbial community structure across a range of grasslands of differing management intensity using CLPP, PLFA and community DNA techniques. Applied Soil Ecology 25:63-84

Haynes RJ (1986) The decomposition process: Mineralization, immobilization, humus formation, and degradation. In: Haynes RJ (ed) Mineral nitrogen in the plant-soil system. Academic Press, Orlando, pp 52-126

Holland E, Detling JK (1990) Plant response to herbivory and belowground nitrogen cycling. Ecology 71:1040-1049

Holland EA, Parton WJ, Detling JK, Coppock DL (1992) Physiological responses of plant populations to herbivory and their consequences for ecosystem nutrient flow. Am Nat 140:685-706

Kemp PR, Waldecker DG, Owensby CE, Reynolds JF, Virginia RA (1994) Effects of elevated CO2 and nitrogen fertilization pretreatments on decomposition on tallgrass prairie leaf litter. Plant Soil 165:115-127

Knorr M, Frey SD, Curtis PS (2005) Nitrogen additions and litter decomposition: a meta-analysis. Ecology 86:3252-3257

Jaramillo V, Detling JK (1988) Grazing history, defoliation, and competition: effects on shortgrass production and nitrogen accumulation. Ecology 69:1599-1608

Lavado R, Taboada M (1988) Water, salt and sodium dynamics in a natraquoll in Argentina. Catena 15:577-594

Loreti J, Oesterheld M, Sala OE (2001) Lack of intraspecific variation in resistance to defoliation in a grass that evolved under light grazing pressure. Plant Ecol 157:195-202
Madritch MD, Hunter MD (2002) Phenotypic diversity influences ecosystem functioning in an oak sandhills community. Ecology 83:2084-2090

McNaughton SJ, Chapin SF III (1985) Effects of phosphorus nutrition and defoliation on $\mathrm{C} 4$ graminoids from the Serengeti plains. Ecology 66:1617-1629

McNaughton SJ, Banyikwa FF, McNaughton MM (1997) Promotion of the cycling of diet-enhancing nutrients by African grazers. Science 278:1798-1800

McNaughton SJ, Banyikwa FF, McNaughton MM (1998) Root biomass and productivity in a grazing ecosystem: the Serengeti. Ecology 79:587-592

Moretto A, Distel R, Didoné N (2001) Decomposition and nutrient dynamics of leaf litter and roots from palatable and unpalatable grasses in a semi-arid grassland. Applied Soil Ecology 18:31-37

Murray PJ, Hatch DJ, Dixona ER, Stevens RJ, Laughlin RJ, Jarvis SC (2004) Denitrification potential in a grassland subsoil: effect of carbon substrates. Soil Biol Biochem 36:545-547

Olofsson J, Oksanen L (2002) Role of litter decomposition for the increased primary production in areas heavily grazed by reindeer: a litterbag experiment. Oikos 96:507-515

Painter EL, Detling JK, Steingraeber DA (1993) Plant morphology and grazing history: relationships between native grasses and herbivores. Vegetatio 106:37-62

Parton WJ, Stewart JWB, Cole CV (1988) Dynamics of C, N, P and $\mathrm{S}$ in grassland soils: a model. Biogeochemistry 5:109-131

Pastor J, Cohen Y (1997) The functional diversity of plant species, and the cycling of nutrients in ecosystems. Theor Popul Biol 51:165-179

Pastor J, Dewey B, Naiman R, McInnes P, Cohen Y (1993) Moose browsing and soil fertility in the boreal forest of Isle Royale national park. Ecology 74:467-480

Perelman SB, León RJC, Oesterheld M (2001) Cross-scale vegetation patterns of Flooding Pampa grasslands. Journal of Ecology 89:562-577

Piñeiro G, Paruelo JM, Oesterheld M (2006) Potential longterm impacts of livestock introduction on carbon and nitrogen cycling in grasslands of Southern South America. Global Change Biology 12:1267-1284

Polley HW, Detling JK (1988) Herbivory tolerance of Agropyron smithii populations with different grazing histories. Oecologia 77:261-268

Ponnamperuma FN (1984) Effects of flooding on soils. In: Kozlowsky TT (ed) Flooding and plant growth. Academic, New York, pp 10-45

Ruess RW, McNaughton SJ (1987) Grazing and the dynamics of nutrient and energy regulated microbial processes in the Serengeti grasslands. Oikos 49:101-110

Rusch GM, Oesterheld M (1997) Relationship between productivity, and species and functional group diversity in grazed and nongrazed Pampa grassland. Oikos 78:519-526

Sankaran M, Augustine DJ (2004) Large herbivores suppress decomposer abundance in a semiarid grazing ecosystem. Ecology 85:1052-1061

Schweitzer JA, Bailey JK, Hart SC, Wimp GM, Chapman SK, Whitham TG (2005) The interaction of plant genotype and herbivory decelerate leaf litter decomposition and alter nutrient dynamics. Oikos 110:133-145 
Seagle SW, McNaughton SJ (1992) Spatial variation in forage nutrient concentrations and the distribution of Serengeti grazing ungulates. Landsc Ecol 7:229-241

Semmartin M, Ghersa CM (2006) Intra-specific changes in plant morphology, associated with grazing, and effects on litter quality, carbon and nutrient dynamics during decomposition. Austral Ecology 31:99-105

Semmartin M, Oesterheld M (2001) Effects of grazing pattern and nitrogen availability on primary productivity. Oecologia 126:225-230

Semmartin M, Aguiar MR, Distel R, Moretto AS, Ghersa CM (2004) Litter quality and nutrient cycling affected by grazing-induced replacements in species composition along a precipitation gradient. Oikos 107:149-161

Semmartin M, Oyarzabal M, Loreti J, Oesterheld M (2007) Controls of primary productivity and nutrient cycling in a temperate grassland with year-round production. Austral Ecology 32:416-428

Shariff AR, Biondini ME, Grygiel CE (1994) Grazing intensity effects on litter decomposition and soil nitrogen mineralization. J Range Manag 47:444-449

Silver WL, Miya RK (2001) Global patterns in root decomposition: comparisons of climate and litter quality effects. Oecologia 129:407-419

Smith SE (1998) Variation in response to defoliation between populations of Bouteloua curtipendula var caespitosa (Poaceae) with different livestock grazing histories. Am J Bot 85:1266-1272
Soriano A (1992) Río de la Plata Grasslands. In: Ecosystems of the World. Natural Grasslands. Introduction and Western Hemisphere. Ed. Coupland R. pp. 367-407. Elsevier, Amsterdam

Schweitzer JA, Bailey JK, Hart SC, Wimp GM, Chapman SK, Whitham TG (2005) The interaction of plant genotype and herbivory decelerate leaf litter decomposition and alter nutrient dynamics. Oikos 110:133-145

Tracy BF, Frank DA (1998) Herbivore influence on soil microbial biomass and nitrogen mineralization in a northern grassland ecosystem: Yellowstone National Park. Oecologia 114:556-562

Uriarte M (2000) Interactions between goldenrod (Solidago altissima L.) and its insect herbivore (Trirhabda virgata) over the course of succession. Oecologia 122:521-528

Van Soest PJ, Robertson JB, Lewis BA (1991) Methods for dietary fiber, neutral detergent fiber and nonstarch polysaccharides in relation to animal nutrition. J Dairy Sci 74:3583-3597

Vivanco L, Austin AT (2006) Intrinsic effects of species on leaf litter and root decomposition: a comparison of temprate grasses from North and South America. Oecologia 150:97-107

Wardle DA, Bonner KI, Barker GM (2002) Linkages between plant litter decomposition, litter quality, and vegetation responses to herbivores. Funct Ecol 16:585-595

Wrage N, Velthof GL, Laanbroek HJ, Oenema O (2004) Nitrous oxide production in grassland soils: assessing the contribution of nitrifier denitrification. Soil Biol Biochem 36:229-236 